\title{
Antena Mikrostrip Array 8x2 Elemen untuk Aplikasi Radio Gelombang Mikro
}

\author{
SYAH ALAM', INDRA SURJATI ${ }^{2}$, LYDIA SARI ${ }^{3}$, JUSTIN TANUWIJAYA4 \\ 1,4] urusan Teknik Elektro Universitas Trisakti, Indonesia \\ 2,3Magister Teknik Elektro Universitas Trisakti, Indonesia \\ Email: syah.alam@trisakti.ac.id
}

Received 17 Agustus 2020 | Revised 13 September 2020 | Accepted 27 Oktober 2020

\begin{abstract}
ABSTRAK
Peningkatan gain pada antena mikrostrip polarisasi melingkar menggunakan metode array 8x2 element diusulkan dalam penelitian ini. Antena yang diusulkan dirancang untuk bekerja pada rentang frekuensi 10700 - $11700 \mathrm{MHz}$ untuk sistem komunikasi radio gelombang mikro. Untuk meningkatkan gain, antena yang diusulkan di optimasi menggunakan array dengan 8x2 elemen. Dari hasil pengukuran diperoleh nilai return loss $-22.77 d B$ dan VSWR sebesar 1.156. Bandwidth yang dihasilkan dari antena array $8 \times 2$ elemen adalah $900 \mathrm{MHz}$ dengan rentang frekuensi kerja $10700 \mathrm{MHz}-11600 \mathrm{MHz}$ serta impedansi sebesar 55.87 + j $4.97 \Omega$ pada frekuensi kerja $10925 \mathrm{GHz}$. Gain dari antena array $8 \times 2$ elemen adalah 15.6 dB pada frekuensi kerja $10925 \mathrm{MHz}$. Optimasi dengan metode array 8x2 elemen berhasil meningkatkan Gain sampai dengan $47.76 \%$ dibandingkan dengan desain array $4 \times 2$ element. Antena yang diusulkan cocok dijadikan kandidat untuk digunakan pada sistem komunikasi radio gelombang mikro.
\end{abstract}

Kata kunci: antena, mikrostrip, gain, array, radio gelombang mikro

\begin{abstract}
Gain optimization on a circular polarization microstrip antenna using the $8 \times 2$ element array method is proposed in this study. The proposed antenna is designed to work in the frequency range 10700 - $11700 \mathrm{MHz}$ for microwave radio communication systems. To increase the gain, the proposed antenna is optimized using an array with $8 \times 2$ elements. From the measurement results obtained return value of $-22.77 d B$ and VSWR of 1,156 . The Bandwidth produced from the $8 \times 2$ element antenna array is $900 \mathrm{MHz}$ with a working frequency range of $10700 \mathrm{MHz}$ - $11600 \mathrm{MHz}$ and an impedance of $55.87+j 4.97 \Omega$ at a working frequency of $10925 \mathrm{MHz}$. The gain of the $8 \times 2$ element array antenna is $15.6 \mathrm{~dB}$ at a working frequency of $10925 \mathrm{MHz}$. Optimization with the 8x2 element array method succeeded in increasing Gain by up to $47.76 \%$ compared to the $4 \times 2$ element array design. The proposed antenna is suitable as a candidate for use in microwave radio communication systems.
\end{abstract}

Keywords: microstrip, antenna, gain, array, microwave radio 
Alam, dkk

\section{PENDAHULUAN}

Sistem komunikasi gelombang mikro telah banyak dikembangkan dan digunakan untuk keperluan komunikasi satelit ( $\mathbf{R a n j a n , ~ P . ~ , ~ d k k , ~ 2 0 1 9 ) . ~ B e r d a s a r k a n ~ r e g u l a s i ~ y a n g ~ d i t e t a p k a n ~}$ oleh (Hasyim, 2016) frekuensi kerja dari sistem komunikasi radio gelombang mikro adalah $11 \mathrm{GHz}$ dengan rentang frekuensi kerja $10700 \mathrm{MHz}-11700 \mathrm{MHz}$. Sistem komunikasi radio gelombang mikro memerlukan antena dengan gain yang tinggi agar komunikasi antara radio pemancar dan penerima berlangsung dengan baik. Pada umumnya, antena yang digunakan pada sistem komunikasi radio gelombang mikro memiliki polarisasi vertical dan horizontal. Hal ini menyebabkan sering terjadi overlapping sinyal yang di terima karena adanya cross polarization antara kedua polarisasi yang digunakan sehingga sistem komunikasi terputus. Untuk itu diperlukan antena yang memiliki polarisasi melingkar sehingga dapat mencegah terjadinya hal tersebut. Penggunaan antena mikrostrip untuk sistem komunikasi radio gelombang mikro telah dipaparkan pada beberapa penelitian sebelumnya (MiguelHernández, \& J. D. , Hoyland, R. J. , 2019), (González, S. R. M., \& Márquez, R. T. R., 2019), (Gotra, S., dkk , 2016). Keuntungan dari antena mikrostrip adalah desain yang kompak serta low cost, tetapi antena mikrostrip memiliki beberapa kerugian antara lain bandwidth yang sempit dan gain yang rendah (Fang, 2017), (Lee, K. F., dkk, 2017). Berdasarkan penelitian sebelumnya, peningkatan gain dari antena mikrostrip dapat didapatkan menggunakan beberapa teknik antara lain parasitic (Santiko, A. B., Paramayudha, K., Wahyu, Y., \& Wijanto, H., 2016), (Ding, K., dkk, 2017), array (Zhao, X., dkk, 2017), (Asaadi, M., \& Sebak, A., 2017) dan penambahan slot (Chen, Q., dkk, 2018), (Bakhtiari, A., dkk , 2018). Penelitian sebelumnya yang dilakukan oleh (Surjati, I., dkk, 2019) mengusulkan desain antena mirkrostrip truncated corner dengan array 1x2 elemen yang menghasilkan gain sebesar $8.12 \mathrm{~dB}$ pada frekuensi $10850 \mathrm{MHz}$. Selanjutnya pada penelitian yang diusulan oleh (Alam, S., dkk, 2019) telah berhasil dirancang optimasi antena mikrostrip polarisasi melingkar menggunakan array $4 \times 2$ elemen dengan gain sebesar $10.56 \mathrm{~dB}$ pada frekuensi $10850 \mathrm{MHz}$. Akan tetapi, gain yang dihasilkan dari penelitian sebelumnya belum optimal sehingga perlu dilakukan optimasi. Pada umumnya antena yang digunakan untuk komunikasi radio gelombang mikro menggunakan jenis antena parabolic dengan gain pada rentangan 15-30 dBi dengan lebar berkas sudut pancaran $5^{\circ}-15^{\circ}$ (System, 2020). Penelitian ini mengusulkan optimasi dari penelitian sebelumnya dengan mengoptimasi antena mikrostirp menggunakan array $8 \times 2$ elemen. Tujuan penambahan jumlah elemen untuk menghasilkan gain yang sesuai dengan standar kebutuhan dari sistem komunikasi gelombang mikro. Kelebihan dari antena yang diusulkan adalah memiliki desain yang kompak dan biaya pabrikasi yang terjangkau jika dibandingkan dengan antena parabolic yang biasa digunakan untuk komunikasi radio gelombang mikro. Selain itu, antena yang dirancang juga menghasilkan polarisasi melingkar dengan axial ratio $\leq 3 \mathrm{~dB}$ pada rentang frekuensi kerja $10700 \mathrm{MHz}$.

\section{DESAIN ANTENA}

\subsection{Desain Antena dari Penelitian Sebelumnya}

Pada penelitian sebelumnya, antena yang dirancang menggunakan metode array $4 \times 2$ elemen berhasil dipabrikasi dan diukur performansinya (Alam, S., dkk, 2019). Hasil pabrikasi dari antena yang telah dirancang sebelumnya ditunjukkan pada Gambar 1 . 


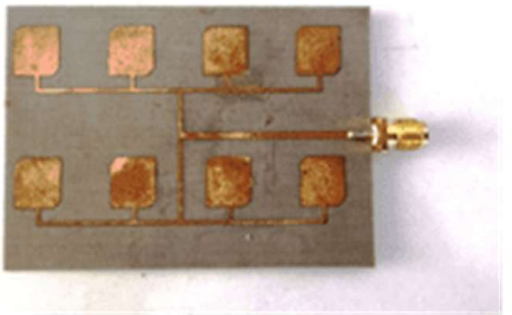

(a)

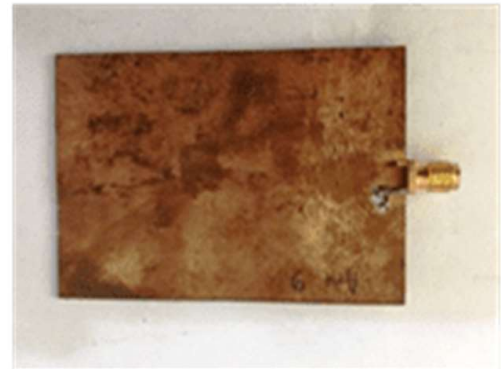

(b)

\section{Gambar 1. Hasil Pabrikasi Antena Mikrostrip Array 4x2 Elemen}

(a) Tampak Depan; (b) Tampak Belakang (Alam, S., dkk, 2019)

\subsection{Desain Antena Array 8x2 Elemen}

Permodelan yang diusulkan dalam penelitian ini adalah array $8 \times 2$ elemen yang disusun secara horizontal (plannar array). Adapun desain dari antena array 8x2 elemen ditunjukkan pada Gambar 2 dan Tabel 1 menunjukkan dimensi dari antena yang diusulkan.

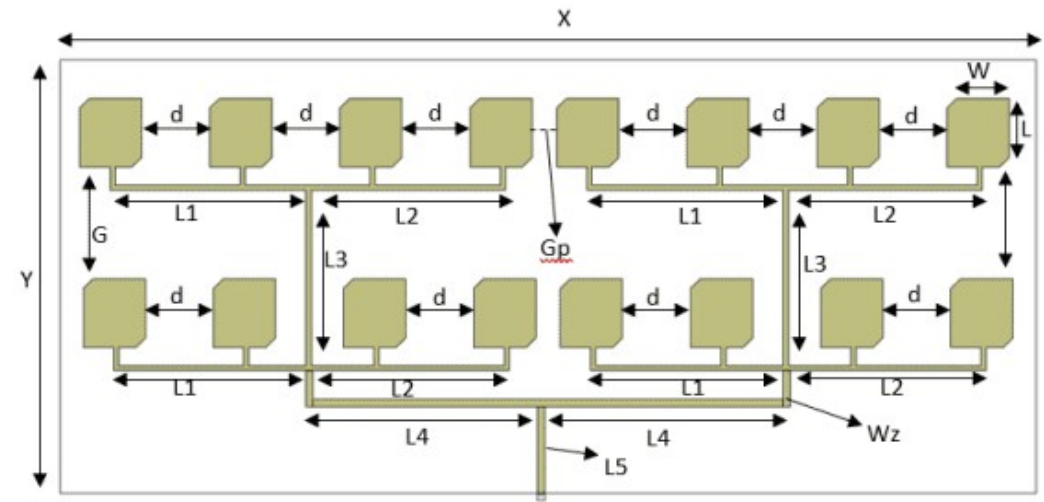

Gambar 2. Permodelan Antena dengan Array 8x2 Elemen

Tabel 1. Dimensi Antena Truncated Corner dengan Array $8 \times 2$ Elemen

\begin{tabular}{|c|c|c|c|}
\hline Parameter & Dimensi & Parameter & Dimensi \\
\hline $\mathrm{X}$ & $135 \mathrm{~mm}$ & $\mathrm{~L} 2$ & $26.8 \mathrm{~mm}$ \\
\hline $\mathrm{Y}$ & $60 \mathrm{~mm}$ & $\mathrm{~L} 3$ & $29 \mathrm{~mm}$ \\
\hline $\mathrm{W}$ & $7.2 \mathrm{~mm}$ & $\mathrm{~L} 4$ & $32 \mathrm{~mm}$ \\
\hline $\mathrm{L}$ & $8.1 \mathrm{~mm}$ & $\mathrm{~L} 5$ & $12 \mathrm{~mm}$ \\
\hline $\mathrm{Wz}$ & $0.7 \mathrm{~mm}$ & $\mathrm{Gp}$ & $3.4 \mathrm{~mm}$ \\
\hline $\mathrm{L} 1$ & $27.1 \mathrm{~mm}$ & $\mathrm{~d}$ & $9.4 \mathrm{~mm}$ \\
\hline $\mathrm{G}$ & $15.6 \mathrm{~mm}$ & $\Delta \mathrm{l}$ & $1.9 \mathrm{~mm}$ \\
\hline
\end{tabular}

Gambar 1 menunjukkan desain antena yang telah di optimasi dengan menambahkan 8 elemen yang dikoneksikan menggunakan saluran mikrostrip dengan impedansi $100 \Omega$ dan $50 \Omega$. Dimensi dari elemen dan potongan tepi pada antena mikrostrip telah dipaparkan dan 
dikembangkan pada penelitian sebelumnya (Alam, S., dkk, 2019), (Surjati, I., dkk, 2019). Tabel 1 menunjukkan dimensi dari permodelan antena menggunakan array $8 \times 2$ elemen dengan jarak antar elemen $d=9.4 \mathrm{~mm}, G=15.6 \mathrm{~mm}$ dan $\mathrm{Gp}=3.4 \mathrm{~mm}$. Dimensi dari jarak antar elemen dan saluran pencatu L1 , L2, L3, L4 , L5 , L6 dan L7 diperoleh dari hasil optimasi dan simulasi menggunakan perangkat lunak AWR Microwave Office.

\subsection{Studi Parameter}

Desain antena yang dihasilkan selanjutnya disimulasikan menggunakan AWR Microwave Office untuk melihat kinerja dari parameter return loss, VSWR , bandwidth dan axial ratio. Untuk mendapatkan hasil terbaik dari simulasi terhadap parameter antena maka dilakukan beberapa tahapan iterasi dengan merubah dan mengontrol dimensi dari X, Y, L4, L5 dan Gp. Tahapan iterasi yang dilakukan ditunjukkan pada Tabel 2 .

Tabel 2. Iterasi Desain Antena Plannar Array 8x2 Elemen

\begin{tabular}{|c|c|c|c|c|c|}
\hline \multirow{2}{*}{ Kondisi } & \multicolumn{5}{|c|}{ Dimensi } \\
\cline { 2 - 6 } & $\mathbf{X}$ & $\mathbf{Y}$ & L3 & L4 & Gp \\
\hline Iterasi 1 & $135 \mathrm{~mm}$ & $60 \mathrm{~mm}$ & $29 \mathrm{~mm}$ & $32 \mathrm{~mm}$ & $3.4 \mathrm{~mm}$ \\
\hline Iterasi 2 & $135 \mathrm{~mm}$ & $56 \mathrm{~mm}$ & $30 \mathrm{~mm}$ & $34 \mathrm{~mm}$ & $7.4 \mathrm{~mm}$ \\
\hline Iterasi 3 & $135 \mathrm{~mm}$ & $60 \mathrm{~mm}$ & $30 \mathrm{~mm}$ & $34 \mathrm{~mm}$ & $7.4 \mathrm{~mm}$ \\
\hline
\end{tabular}

Gambar 3, Gambar 4 dan Gambar 5 menunjukkan hasil simulasi yang didapatkan dari proses iterasi yang dilakukan. Paramater yang di amati dan disimulasikan adalah return loss dan axial ratio. Keseluruhan hasil yang diperoleh dari proses simulasi dan iterasi ditampilkan pada Tabel 3.

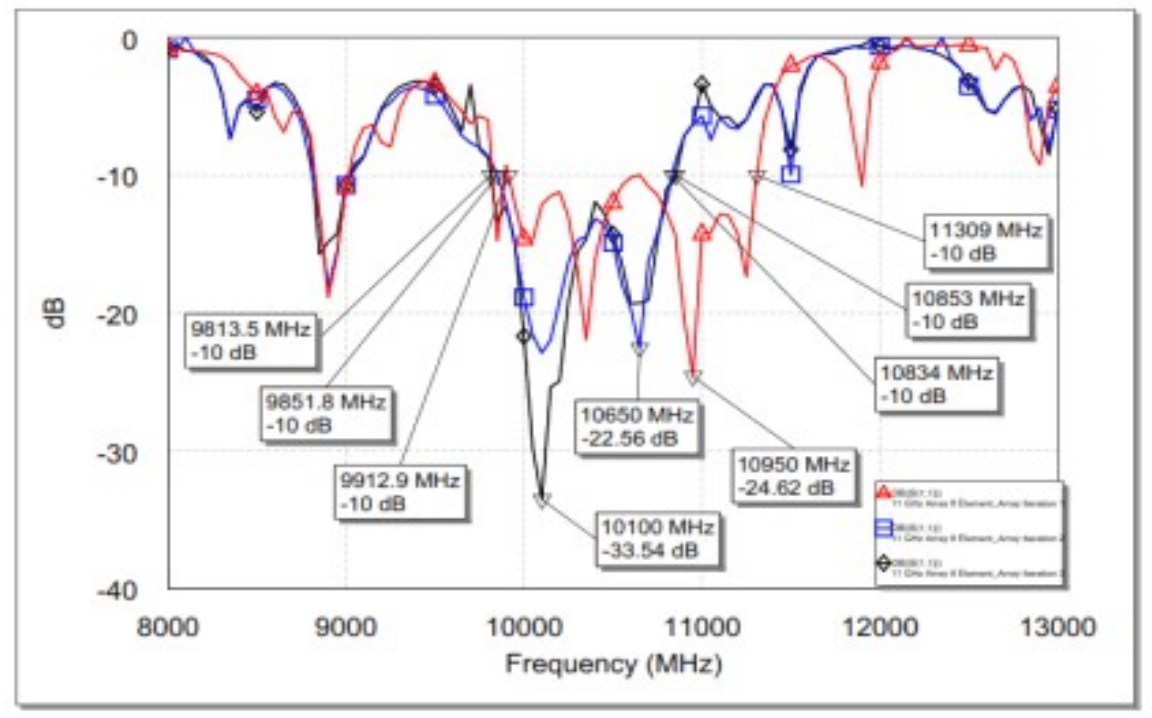

Gambar 3. Hasil Simulasi Return loss dari Proses Iterasi Antena Array 8x2 Elemen 


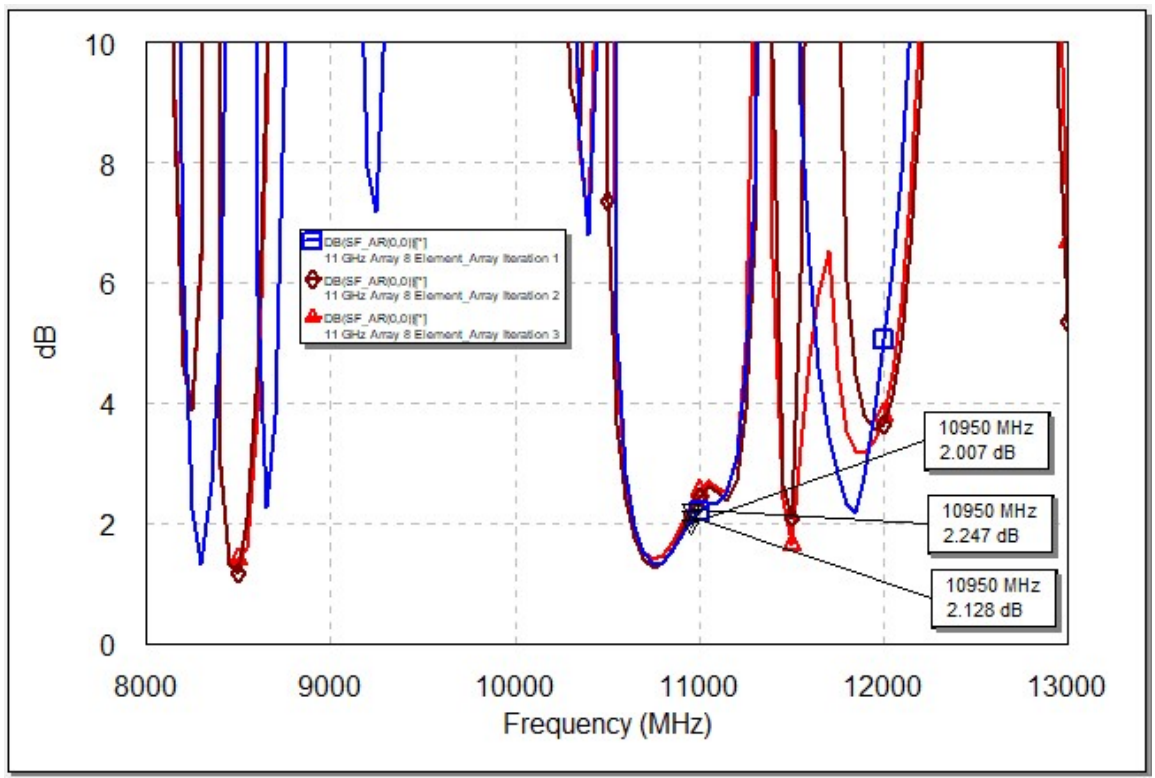

\section{Gambar 4. Hasil Simulasi Axial Ratio dari Proses Iterasi Antena Array 8x2 Elemen}

Gambar 3 menunjukkan hasil simulasi dari proses iterasi yang dilakukan. Hasil simulasi terbaik diperoleh pada iterasi 1 dengan return loss -24.62 dB, VSWR 1.125 dan bandwidth $1397 \mathrm{MHz}$ (9912 MHz - $11309 \mathrm{MHz}$ ) dengan frekuensi keja $10950 \mathrm{MHz}$. Antena yang diusulkan juga telah menghasilkan polarisasi melingkar dengan axial ratio $2.007 \mathrm{~dB}$ pada frekuensi kerja 10700 $\mathrm{MHz}$ seperti yang ditunjukkan pada Gambar 4. Perubahan dimensi saluran pencatu mempengaruhi parameter dan frekuensi kerja dari antena yang diusulkan. Keseluruhan hasil simulasi dari proses iterasi ditunjukkan pada Tabel 3.

Tabel 3. Hasil Iterasi Desain Antena Plannar Array 8x2 Elemen

\begin{tabular}{|c|c|c|c|c|c|}
\hline \multirow{2}{*}{ Kondisi } & \multicolumn{5}{|c|}{ Parameters } \\
\cline { 2 - 6 } & Return loss & VSWR & Bandwidth & Axial Ratio & Frequency \\
\hline Iterasi 1 & $-24.62 \mathrm{~dB}$ & 1.125 & $1397 \mathrm{MHz}$ & $2.007 \mathrm{~dB}$ & $10950 \mathrm{MHz}$ \\
\hline Iterasi 2 & $-20.56 \mathrm{~dB}$ & 1.251 & $1021 \mathrm{MHz}$ & $2.128 \mathrm{~dB}$ & $10700 \mathrm{MHz}$ \\
\hline Iterasi 3 & $-22.56 \mathrm{~dB}$ & 1.161 & $983 \mathrm{MHz}$ & $2.247 \mathrm{~dB}$ & $10650 \mathrm{MHz}$ \\
\hline
\end{tabular}

Tabel 3 menunjukkan bahwa pada iterasi 1 dan iterasi 3 terjadi pergeseran frekuensi kerja menjadi 10950 MHz dan 10650 MHz. Selain itu, bandwidth dan axial Ratio dari antena yang diusulkan juga mengalami perubahan. Hal ini dikarenakan adanya perubahan distribusi arus yang mengalir pada patch antena. Simulasi terbaik didapatkan pada iterasi ke 1 dengan frekuensi kerja $10950 \mathrm{MHz}$. Setelah melakukan proses simulasi terhadap parameter return loss, VSWR dan axial ratio dari kedua permodelan antena, selanjutnya dilakukan simulasi gain dari antena yang diusulkan. Adapun gain dari antena yang diusulkan ditunjukkan melalui Gambar 5. 


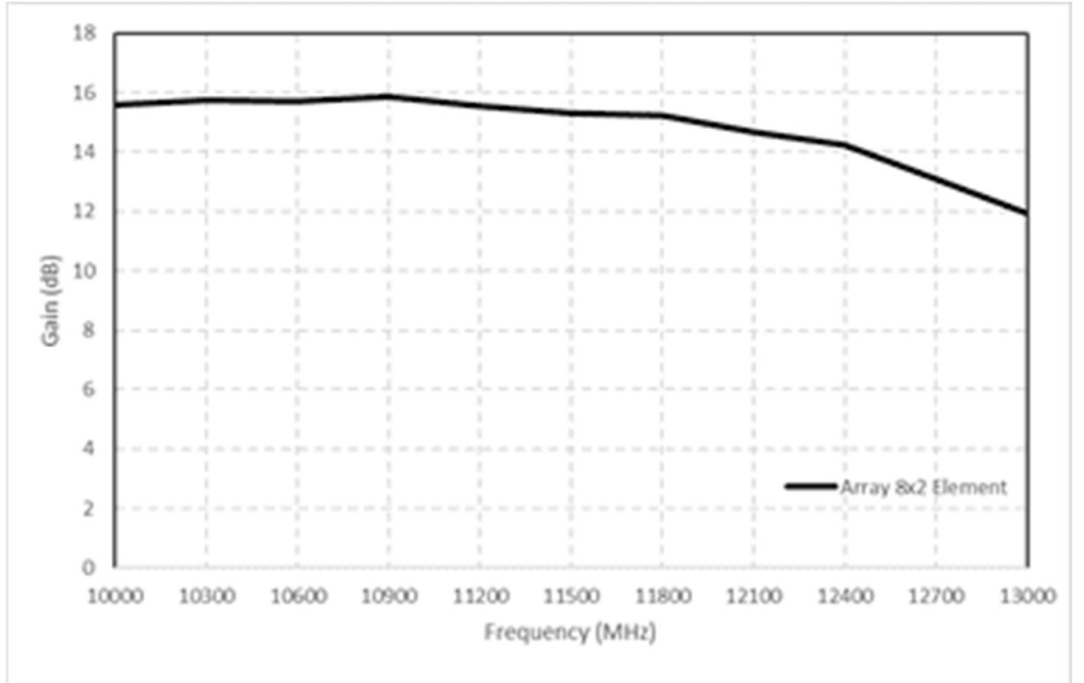

Gambar 5. Hasil Simulasi Gain dari Antena Array 8x2 Elemen

\section{REALISASI DAN PENGUKURAN ANTENA}

\subsection{Realisasi Antena}

Pada penelitian ini, antena yang diusulkan dipabrikasi menggunakan jenis substrat Arlon LX 217 CuClad dengan spesifikasi seperti yang ditunjukkan pada Tabel 4.

Tabel 4. Spesifikasi Substrat Jenis Arlon LX 217 CuClad

\begin{tabular}{|l|l|l|}
\hline No. & \multicolumn{1}{|c|}{ Parameter } & \multicolumn{1}{c|}{ Nilai } \\
\hline 1. & Konstanta Dielektrik $\left(\varepsilon_{\mathrm{r}}\right)$ & 2.2 \\
\hline 2. & Ketebalan $(\mathrm{h})$ & $0.787 \mathrm{~mm}$ \\
\hline 3. & Rugi-rugi Dielektrik / Loss Tan $(\tan \mathrm{a})$ & 0.0009 \\
\hline 4. & Cooper Cladding & $1 \mathrm{Oz}, 35 \mathrm{~mm}$ \\
\hline 5. & Volume Resistivity & $2.3 \times 10^{8} \mathrm{M} \Omega / \mathrm{cm}$ \\
\hline
\end{tabular}

Jenis konektor yang digunakan adalah RP-SMA jenis female yang terhubung dengan patch antena melalui saluran pencatu microstrip line. Konektor dihubungkan dengan cara di solder menggunakan timah. Inti konektor dihubungkan dengan saluran microstrip line sedangkan body dari konektor terhubung dengan ground plane yang berada di bagian belakang patch antena. Hasil pabrikasi dari antena array 8x2 elemen ditunjukkan pada Gambar 6.

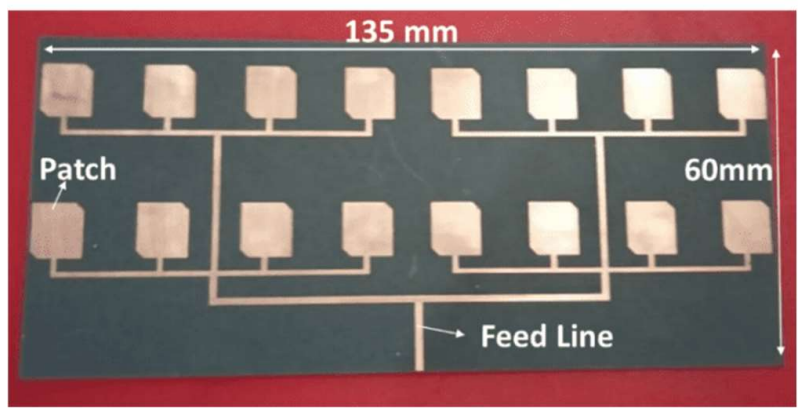

Gambar 6. Hasil Pabrikasi Antena Array 8x2 Elemen 


\subsection{Pengukuran Antena}

Setelah melakukan proses perancangan dan pabrikasi , tahapan selanjutnya adalah melakukan proses pengukuran dari antena yang diusulkan. Proses pengukuran dilakukan dengan menggunakan alat ukur Vector Network Analyzer (VNA) Advantest R3770. Pengukuran dilakukan di Pusat Penelitian Elektronika dan Telekomunikasi (PPET) LIPI Bandung. Parameter yang diukur adalah return loss (koefisien refleksi), VSWR dan impedansi. Proses pengukuran antena ditujukkan pada Gambar 7.

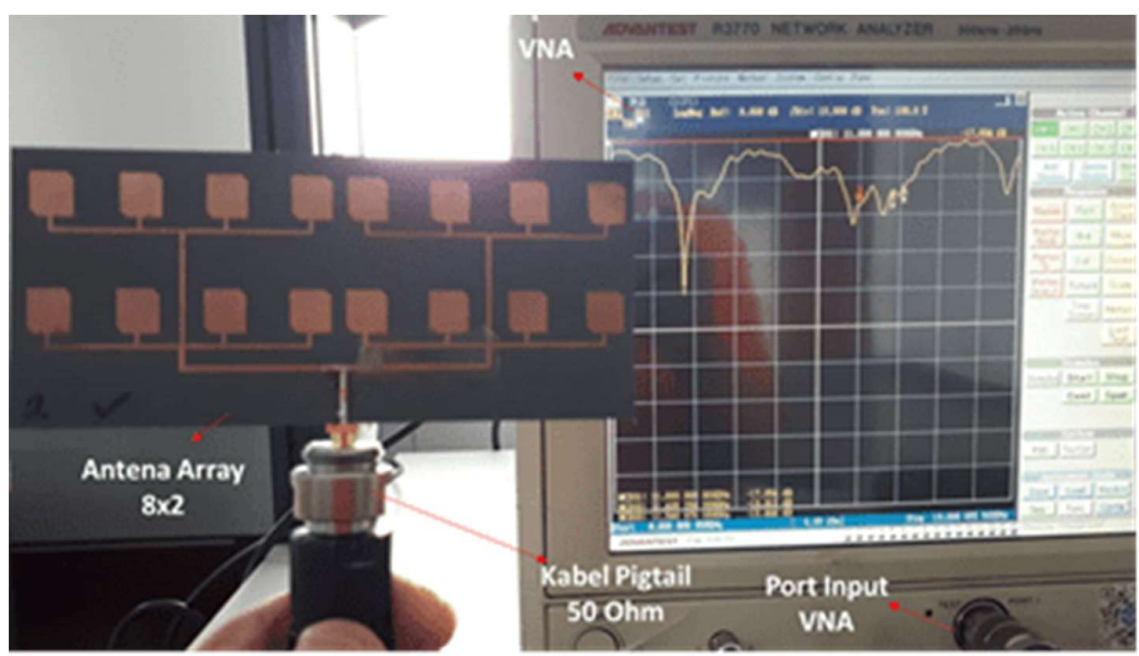

Gambar 7. Proses Pengukuran Antena Array 8x2 Elemen

Proses pengukuran dilakukan dengan menghubungkan antena yang dirancang menggunakan kabel pigtail ke port VNA yang menggunakan konektor $\mathrm{N}$ Female. Hasil pengukuran dari parameter return loss (koefisien refleksi),VSWR dan impedansi ditunjukkan pada Gambar 8 dan Gambar 9.

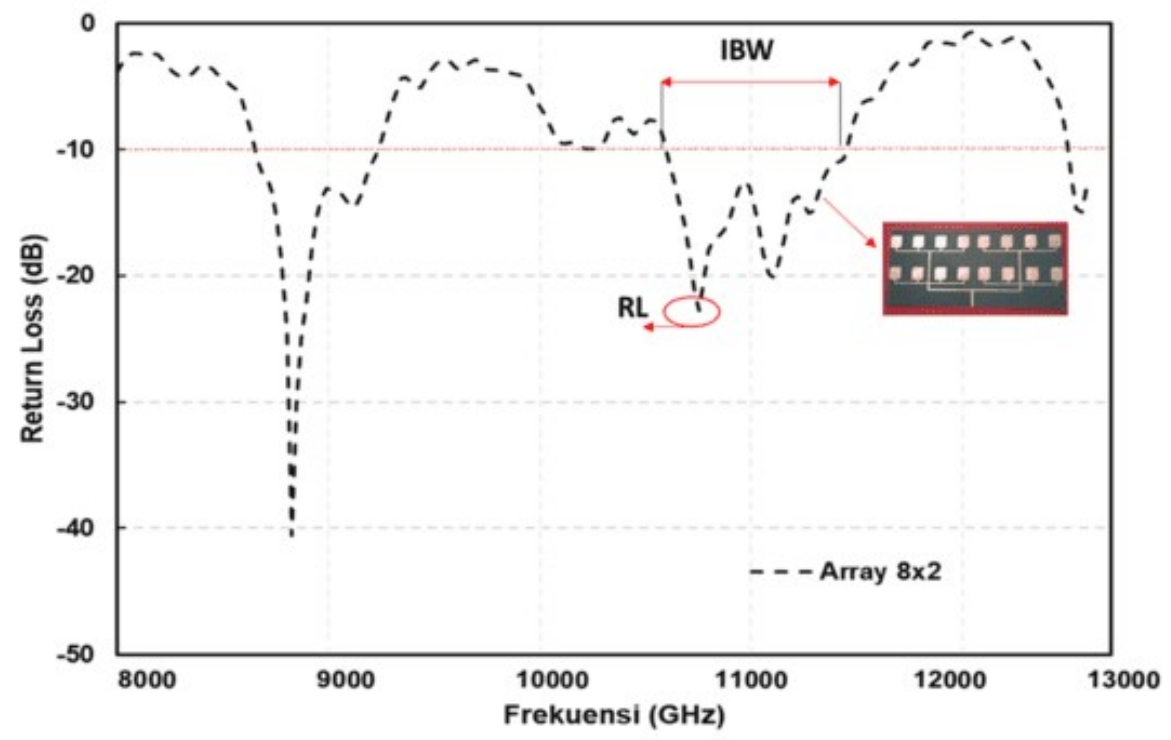

Gambar 8. Hasil Pengukuran Return loss 


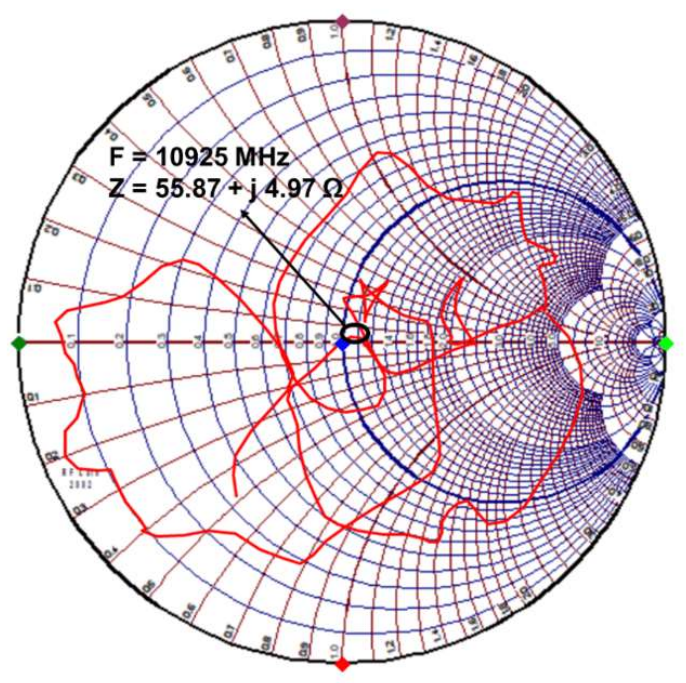

Gambar 9. Hasil Pengukuran Impedansi

Hasil pengukuran return loss pada antena array 8x2 elemen ditunjukkan pada Gambar 8. Dari proses pengukuran didapatkan bahwa antena array 8x2 elemen bekerja pada frekuensi 10925 $\mathrm{MHz}$ dengan nilai return loss $-22.77 \mathrm{~dB}$ dan VSWR sebesar 1.156. Bandwidth yang dihasilkan dari antena array 8x2 elemen adalah $900 \mathrm{MHz}$ dengan rentang frekuensi kerja $10700 \mathrm{MHz}-$ $11600 \mathrm{MHz}$. Batasan nilai return loss yang ditetapkan adalah $\leq-10 \mathrm{~dB}$ dan VSWR $\leq 2$. Impedansi dari antena array $8 \times 2$ elemen adalah $55.87+\mathrm{j} 4.97 \Omega$ pada frekuensi kerja 10925 $\mathrm{MHz}$ seperti yang ditunjukkan pada Gambar 9, yang artinya mendekati nilai impedansi ideal yaitu $50 \pm j 0 \Omega$. Dari hasil pengukuran terhadap kedua antena dapat disimpulkan bahwa antena yang dirancang telah bekerja dengan baik pada frekuensi $10925 \mathrm{MHz}$ dengan nilai return loss

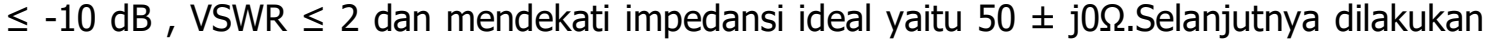
perbandingan hasil simulasi dan pengukuran yang telah dilakukan untuk melihat ketepatan dari desain antena yang diusulkan. Gambar 10 menunjukkan perbandingan antara hasil simulasi dan pengukuran terhadap parameter return loss.

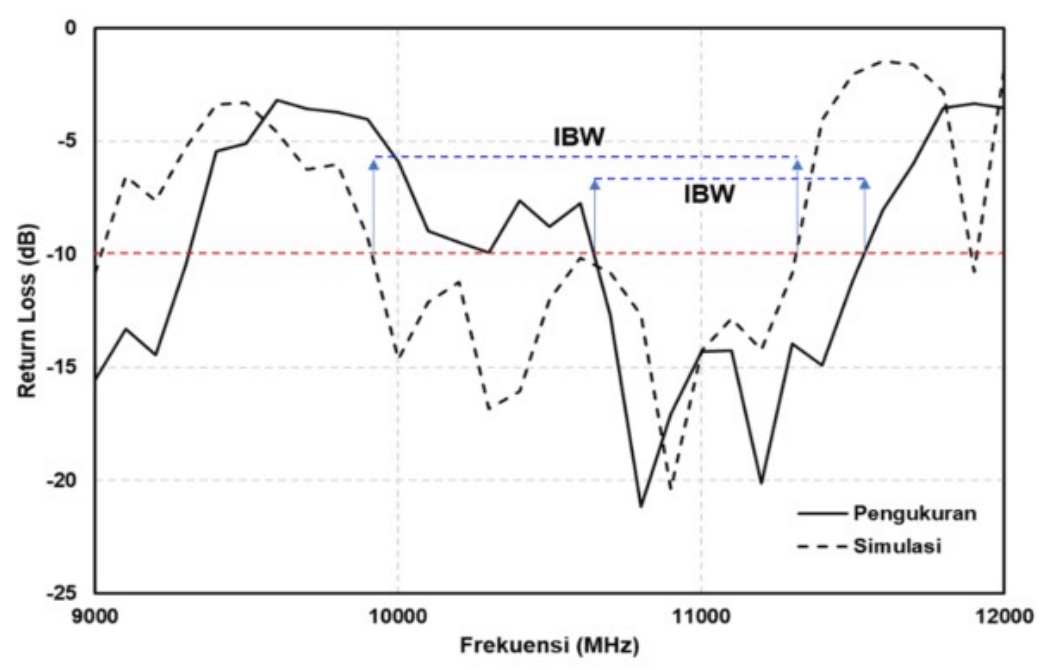

Gambar 10. Perbandingan Hasil Simulasi dan Pengukuran 
Gambar 10 menunjukkan bahwa antena yang diusulkan mengalami penyempitan bandwidth pada proses pengukuran jika dibandingkan dengan hasil yang didapatkan dari proses simulasi. Hal ini dikarenakan tingkat ketelitian pabrikasi yang kurang baik sehingga menyebabkan terjadinya pergeseran frekuensi dan penyempitan impedance bandwidth(IBW). Namun secara keseluruhan antena masih bekerja pada rentangan frekuensi $10700-11600 \mathrm{MHz}$.

\subsection{Pengukuran Pola Radiasi dan Gain}

Pada penelitian ini pengukuran pola radiasi dan gain dilakukan di ruang anechoic chamber yang berada di Pusat Penelitian Elektronika dan Telekomunikasi (PPET) di Bandung. Pengukuran pola radiasi dilakukan dengan menghubungkan antena rancangan yang terpasang di tiang ukur dengan signal generatoryang di atur bekerja pada frekuensi $10.9 \mathrm{GHz}$ dan daya pancar $0 \mathrm{dBm}$. Antena yang dirancang di posisikan sebagai antena penerima ( $\mathrm{Rx})$ dan antena pembanding tipikal horn digunakan sebagai pemancar (Tx). Antena pembanding memiliki gain sebesar $12 \mathrm{~dB}$ dan terpasang di tiang ukur. Jarak antara antena pembanding dan antena rancangan adalah $100 \mathrm{~cm}$. Pola radiasi bidang $\mathrm{E}$ (elektrik) dari antena diukur dengan memutar antena secara vertical dari sudut $0-360^{\circ}$ sedangkan pola radiasi bidang $\mathrm{H}$ (magnet) diukur dengan memutar antena secara horizontal dari sudut $0-180^{\circ}$. Konfigurasi pengukuran pola radiasi ditunjukkan pada Gambar 11 dan Gambar 12.

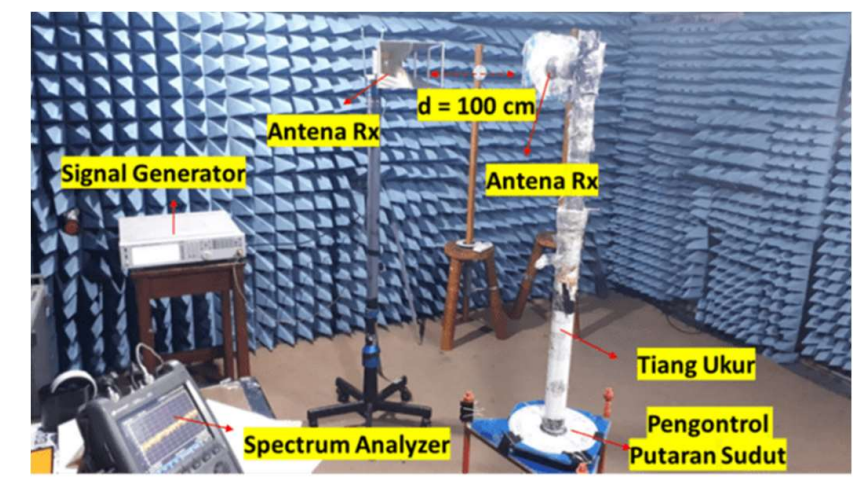

\section{Gambar 11. Konfigurasi Pengukuran Pola Radiasi}

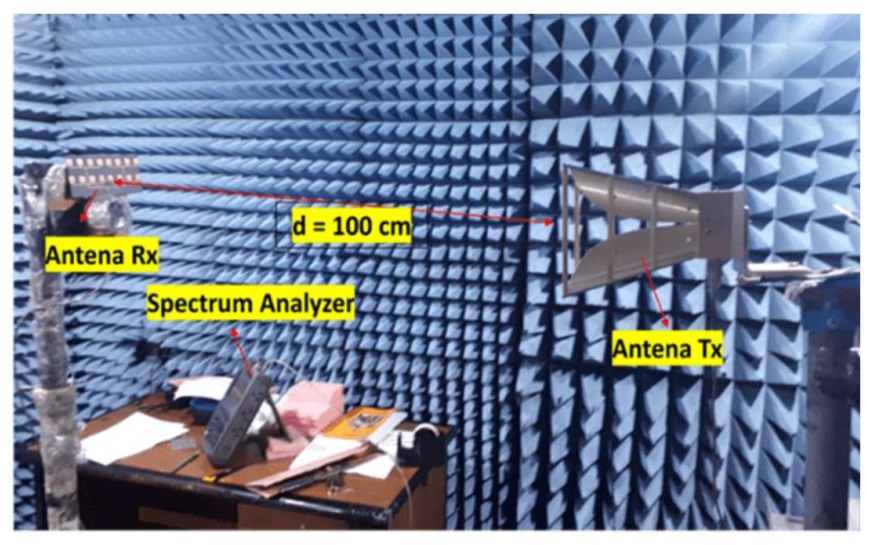

\section{Gambar 12. Penempatan Antena Tx dan Antena Rx}

Hasil pengukuran level penerimaan sinyal dari kedua antena pada bidang $\mathrm{E}$ dan $\mathrm{H}$ yang diusulkan ditunjukkan pada Gambar 13. Batas lebar sudut berkas pancaran $(\phi)$ diamati pada perpotongan nilai level penerimaan - $30 \mathrm{~dB}$. Pola radiasi bidang vertical dan horizontal dari 
kedua antena yang diusulkan pada ditunjukkan pada Gambar 13.

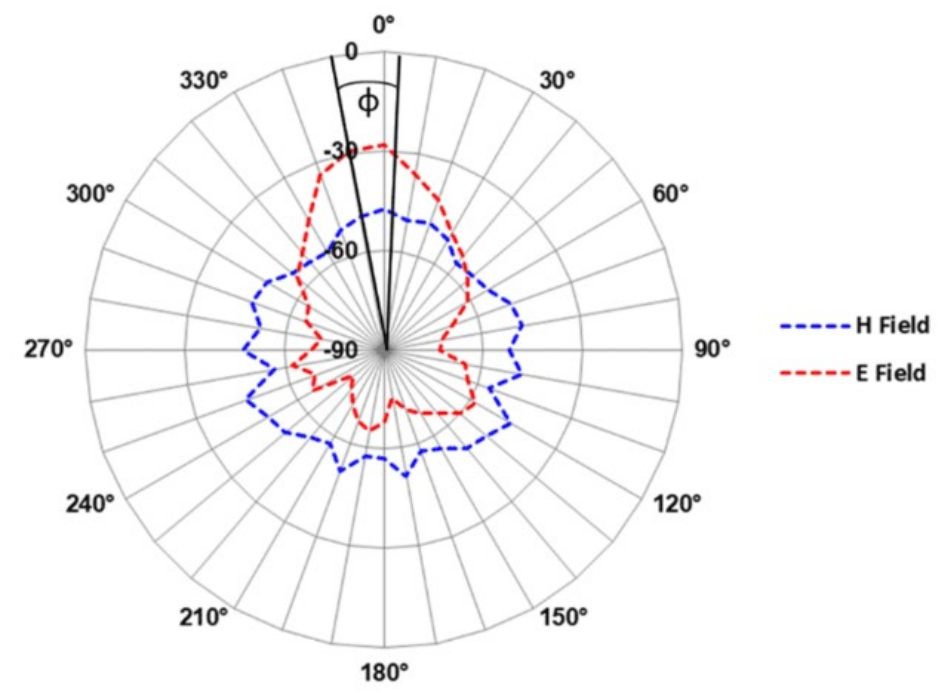

\section{Gambar 13. Pola Radiasi Antena Array 8x2 Elemen}

Gambar 13 menunjukkan pola pancaran antena pada bidang vertical (E-Field) dan horizontal ( $H$-Field) yang diamati dari sudut $0-360^{\circ}$ menggunakan alat ukur spectrum analyzer pada frekuensi kerja $10925 \mathrm{MHz}$. Pola pancar dari antena yang diusulkan bersifat ke satu arah (directional) dengan level penerimaan sinyal terendah pada $-78 \mathrm{dBm}$. Lebar sudut berkas pancaran dari antena yang dirancang adalah $12^{\circ}$. Gain dari antena yang diusulkan (G $\mathrm{G}_{\text {Ant }}$ ) didapatkan dengan membandingkan level penerimaan sinyal dari antena yang dirancang pada saat diposisikan sebagai antena pemancar $\left(P_{T x}\right)$ dan penerima $\left(P_{R x}\right)$ lalu di tambahkan dengan gain dari antena pembanding $\left(\mathrm{G}_{\mathrm{Ap}}\right)$ yang digunakan pada saat proses pengukuran seperti yang ditunjukkan pada Persamaan (1). Gain antena pembanding yang digunakan dalam pengukuran adalah $12 \mathrm{~dB}$ pada frekuensi $10925 \mathrm{MHz}$.

$$
G_{A n t}(d B)=P_{T x}(d B m)-P_{R x}(d B m)+G_{A p}(d B)
$$

Hasil pengukuran level penerimaan sinyal dari kedua antena yang diusulkan yang dilakukan di ruang anechoic chamber pada frekuensi $10925 \mathrm{MHz}$ dan daya pancar $0 \mathrm{dBm}$ ditunjukkan pada Tabel 5. Perbandingan peningkatan gain dari kedua permodelan antena ditunjukkan pada Tabel 6.

Tabel 5. Level Penerimaan Sinyal dari Antena yang Diusulkan

\begin{tabular}{|c|c|c|c|c|}
\hline Model Antena & $\mathbf{P}_{\mathbf{T X}} \mathbf{( d B m )}$ & $\left.\mathbf{P}_{\mathbf{R x}} \mathbf{( d B m}\right)$ & $\left.\mathbf{G}_{\mathbf{A p}} \mathbf{( d B}\right)$ & $\mathbf{G}_{\text {Ant }}(\mathbf{d B})$ \\
\hline Array 8x2 Elemen & -43.8 & -47.4 & 12 & 15.6 \\
\hline
\end{tabular}

Tabel 6. Perbandingan Gain dari Keseluruham Model Antena

\begin{tabular}{|c|c|}
\hline Gain & G Ant $\mathbf{( d B})$ \\
\hline Array $8 \times 2$ Elemen & 15.6 \\
\hline Array $4 \times 2$ Elemen & 10.56 \\
\hline
\end{tabular}


Tabel 5 menunjukkan bahwa antena dengan metode array 8x2 elemen memiliki penguatan yang lebih baik dari metode array 4x2 elemen yaitu $15.6 \mathrm{~dB}$. Dari hasil tersebut dapat dilihat bahwa penambahan elemen pada antena dengan model $8 \times 2$ telah berhasil meningkatkan gain dari antena yang telah di desain sebelumnya dengan metode array $4 \times 2$ elemen sampai dengan $47.16 \%$ seperti yang ditunjukkan pada Tabel 6 .

\section{KESIMPULAN}

Pada penelitian ini dilakukan pengembangan terhadap antena mikrostrip yang telah dirancang sebelumnya dengan menambahkan jumlah elemen pada metode array menjadi 16 elemen. Tahapan optimasi dilakukan dengan menggunakan permodelan plannar array 8x2 elemen. Tujuan dari penambahan elemen pada metode array adalah untuk meningkatkan nilai gain dari antena yang dirancang. Dari hasil pengukuran diperoleh nilai return loss $-22.77 \mathrm{~dB}$ dan VSWR sebesar 1.156. Bandwidth yang dihasilkan dari antena array 8x2 elemen adalah 900 $\mathrm{MHz}$ dengan rentang frekuensi kerja $10700 \mathrm{MHz}-11600 \mathrm{MHz}$ serta impedansi sebesar 55.87 + j $4.97 \Omega$ pada frekuensi kerja $10925 \mathrm{GHz}$. Gain dari antena array 8x2 elemen adalah 15.6 $\mathrm{dB}$ pada frekuensi kerja $10925 \mathrm{MHz}$ dengan lebar sudut berkas pancar $12^{\circ}$. Optimasi dengan metode array 8x2 elemen berhasil meningkatkan Gain sampai dengan $47.76 \%$ dibandingkan dengan desain array 4x2 element. Antena yang diusulkan cocok dijadikan kandidat untuk digunakan pada sistem komunikasi radio gelombang mikro.

\section{UCAPAN TERIMA KASIH}

Ucapan terima kasih kami sampaikan kepada Lembaga Penelitian Universitas Trisakti yang telah membiayai penelitian ini melalui Hibah Internal tahun akademik 2019/2020

\section{DAFTAR RUJUKAN}

Alam, S., Surjati, I., Ningsih, Y. K., Sari, L., Syukriati, E., \& Safitri, A. (2019). Design of Truncated Microstrip Antenna with Array $4 \times 2$ for Microwave Radio Communication. 2019 IEEE Conference on Antenna Measurements \& Applications (CAMA), (pp. 1-4). Bali: Universitas Indonesia.

Asaadi, M., \& Sebak, A. (2017). Gain and Bandwidth Enhancement of $2 \times 2$ Square Dense Dielectric Patch Antenna Array Using a Holey Superstrate. IEEE Antennas and Wireless Propagation Letters, $1-1$.

Bakhtiari, A., Sadeghzadeh, R. A., \& Moghadasi, M. N. . (2018). Gain Enhanced Miniaturized Microstrip Patch Antenna Using Metamaterial Superstrates. IETE Journal of Research, 635-640.

Chen, Q., Zhang, H., Shao, Y. J., \& Zhong, T. (2018). Bandwidth and Gain Improvement of an L-Shaped Slot Antenna With Metamaterial Loading. IEEE Antennas and Wireless Propagation Letters, 17(8), 1441-1415. 
Ding, K., Gao, C., Yu, T., Qu, D., \& Zhang, B. (2017). Gain-Improved Broadband Circularly Polarized Antenna Array With Parasitic Patches. IEEE Antennas and Wireless Propagation Letters, 16, 1468-1471.

Fang, D. G. (2017). Microstrip Patch Antennas, "Antenna Theory and Microstrip Antennas".

González, S. R. M., \& Márquez, R. T. R. (2019). 12-18 GHz Microwave Frequency Band Microstrip Patch Antenna Design for the Radio Implant Medical Devices Application. Telematics and Computing, 110-120.

Gotra, S., Hashim, Z., Pani, S., Tripathy, M. R., \& Banwari, A. ( 2016). C-band microstrip patch linear array antenna for microwave radio relay. CSI Transactions on ICT, 4(2), 151156.

Hasyim, A. (2016). Planning and analysis of the reliability of line of sight microwave radio communication system on 12750-13250 MHz band. Buletin Pos dan Telekomunikasi, $14(2), 147-160$.

Lee, K. F., Luk, K. M., \& Lai, H. W. . (2017). Microstrip Patch Antennas.

Miguel-Hernández, J. D. , Hoyland, R. J. . (2019). Fundamentals of horn antennas with low cross-polarization levels for radioastronomy and satellite communications. Journal of Instrumentation, 14(2), R08001-R08001.

Ranjan, P. , Sur, S. , Pandey, V.K. (2019). Multiple Mode Resonator Based Triple Band Filter for WLAN, Intelligent Transportation System, Satellite Communication and X-Band Applications. 2019 9th Annual Information Technology, Electromechanical Engineering and Microelectronics Conference (IEMECON) (pp. 1-4). Delhi: University of Engineering \& Management.

Santiko, A. B., Paramayudha, K., Wahyu, Y., \& Wijanto, H. (2016). Design and realization multi layer parasitic for gain enhancement of microstrip patch antenna. International Seminar on Intelligent Technology and Its Applications (ISITIA) (pp. 1-4). Bali: Institut Teknologi Sepuluh Nopember.

Surjati, I., Alam, S., Sari, L., Ningsih, Y. K., Syukriati, E., \& Safitri, A. (2019). Circular Polarization Microstrip Antenna Array $1 \times 2$ For Microwave Radio Communication. IEEE International Conference on Communication, Networks and Satellite (COMNETSAT) (pp. 1-4). Makassar: Universitas Hasanudin.

System, R. F. (2020). http://www2.Ifsworld.com. Diambil kembali dari http://www2.rfsworld.com/RFS_Edition4/pdfs/Microwave_Solid_Antennas_267322.pdf 
Zhao, X., Huang, Y., Li, J., Zhang, Q., \& Wen, G. (2017). Wideband high gain circularly polarized UHF RFID reader microstrip antenna and array. AEU - International Journal of Electronics and Communications, 77, 76-81. 